\title{
ANALISIS KESULITAN BELAJAR MATEMATIKA TERHADAP SISWA KELUARGA “BROKEN HOME” DI SMA USWATUN HASANAH JAKARTA TIMUR
}

\author{
Mohamad Lutfi Nugraha \\ Program Studi Informatika, Universitas Indraprasta PGRI \\ muhammadlutfinugraha@gmail.com
}

\begin{abstract}
Tujuan dari penelitian ini adalah untuk mengetahui kesulitan belajar matematika siswa yang mempunyai masalah dengan keluarganya atau broken home. Tempat penelitian ini adalah SMA swasta di Jakarta Timur yaitu SMA Uswatun Hasanah. Dengan sampel penelitian adalah siswa yang mempunyai masalah di luar sekolah yaitu masalah dengan keluarganya. Metode penelitian ini adalah survei eksploratif dengan pendekatan kualitatif. Pengumpulan data penelitian ini adalah wawancara, observasi dan dokumen dari subjek penelitian. Dua anak broken home menjadi subjek penelitian ini. Hasil dari penelitian ini menunjukan bahwa proses kegiatan belajar matematika untuk siswa yang broken home perlu penanganan khusus berupa wejangan dan semangat dari guru matematika, guru BK, dan wali kelas serta diharapkan diberikan metode pembelajaran yang efektif supaya membuat siswa lebih fokus dalam belajar dan lebih dewasa dalam menghadapai masalahnya.
\end{abstract}

Kata Kunci : Kesulitan BelajarMatematika, Broken Home

\begin{abstract}
The purpose of this study is to find out the difficulties of learning mathematics students who have problems with their families or broken home. The place of this research is a private high school in East Jakarta, namely Uswatun Hasanah High School. The research sample is students who have problems outside of school, namely problems with their families. The method of this research is an exploratory survey with a qualitative approach. Data collection of this research are interviews, observations and documents from research subjects. Two broken home children were the subjects of this study. The results of this study indicate that the process of learning mathematics for students who are broken home needs special handling in the form of advice and enthusiasm from mathematics teachers, counseling teachers, and homeroom teachers and is expected to be given effective learning methods to make students more focused in learning and more mature in face the problem.
\end{abstract}

Keywords: Mathematics, Broken Home

\section{PENDAHULUAN}

Keluarga broken home mempunyai tendensi atau keinginan untuk menjadikan keluarga yang tidak jelas keberadaannya. Ketika kedua orang tua sudah tidak dapat berkomunikasi dengan baik karena faktorfaktor yang dimiliki mereka, sehingga keindahan dalam berkeluarga sudah tidak dapat dipertahankan lagi, maka jalan terakhirnya adalah bercerai. Apabila kedua orang tua ini memaksakan untuk tetap mempertahankan keutuhan keluarga tanpa adanya kehangatan dalam rumah secara psikologis mereka sudah berpisah.
Dampak perpisahan bagi anak adalah anak menjadi mudah emosi, frustrasi, dan ingin menyalurkannya dengan melakukan halhal yang berbenturan dengan peraturan, seperti melawan dan lain- lainnya. Dan apabila anak tinggal bersama dengan ibu, maka figur dari seorang ayah akan hilang. Ketika figur itu menghilang, kebanyakan anak tidak begitu takut dengan ibunya. Kehilangan jati diri pada anak adalah dampak lain dari sebuah perpisahan orang tua, mendapatkan status sebagai anak cerai memberikan suatu perasaan berbeda dari anak-anak lain [1]. Sifat negatif yang 
dimiliki kedua orang tua yang tidak memberikan kehangatan dalam berkeluarga dengan ego dan tidak pernah punya waktu untuk berkumpul dengan keluarga berdampak negatif kepada anak dalam belajar, anak akan mengalami kesulitan dalam belajar terutama matematika yang mempunyai tingkat kesukaran yang tinggi.

Menurut [2] penyebab timbulnya keluarga broken home dikarenakan beberapa faktor yaitu kesibukan orang tua dalam mencari materi yang berlebihan sehingga tidak memperhatikan waktu dengan anak. Faktor lainnya adalah perceraian, ini membuat frustasi anak sehingga berdampak negatif terhadap psikis anak tersebut. Faktor yang membuat keluarga broken home juga disebabkan oleh sifat ego masing-masing orang tua. Faktor lainnya adalah sedikitnya ilmu agama atau jauh dari Tuhan.

Pendidikan nasional berfungsi untuk membentuk karakter dan peradaban bangsa yang bermartabat untuk mencerdaskan kehidupan bangsa dan mengembangkan kemampuan, bertujuan untuk mengembangkan potensi siswa agar menjadi manusia yang beriman dan bertakwa kepada Tuhan Yang Maha Esa, berakhlak mulia, sehat, berilmu, cakap, kreatif, mandiri, dan menjadi warga negara yang demokratis, serta bertanggung jawab.

Pendidikan merupakan bimbingan atau pertolongan yang diberikan oleh orang dewasa kepada perkembangan anak untuk mencapai kedewasaannya dengan tujuan agar anak dapat melaksanakan tugas hidupnya sendiri tidak dengan bantuan orang lain. Pendidikan ini merupakan awal yang sangat penting untuk seorang anak,karena melatih mereka untuk membaca dengan benar, mempertajam kemampuan dalammenghitung serta berpikir.
Oleh sebab itu setiap siswa berhak mendapatkan pendidikan yang bagus, walaupun siswa tersebut mempunyai suatu permasalahan dengan keluarganya. Sebagai tenaga pendidik harus mempunyai motivasi besar untuk mengubah kepribadian siswa yang mempunyai masalah dengan keluarganya sehingga siswa yang broken home mampu melewati masalah itu dan dapat belajar dengan sebaik-baiknya untuk meraih apa yang dicita-citakannya

Siswa yang berlatar belakang dari keluarga broken home akan mengalami kesulitan dalam proses pembelajaran dikarenakan banyaknya tekanan dan fikiran dari luar sekolah yang terbawa ke dalam kelas di sekolah, sehingga konsentrasi siswa tersebut akan terganggu dan tidak akan focus. Dalam pembelajaran matematika siswa akan sulit untuk menangkap apa yang disampaikan oleh gurunya.

Kesulitan belajar merupakan situasi dimana terdapat kendala dalam proses pembelajaran untuk mencapai hasil belajar. Kesulitan belajar yang dialami siswa juga disebabkan karena siswa belum menguasai metode langkah-langkah belajar dengan benar. Kesulitan belajar ini muncul dalam setiap siswa disebabkan oleh: siswa belajar tanpa tahu tujuan pembelajaran apa yang dicapai sehingga proses dalam pembelajaran tidak maksimaldan siswa tidak mengetahui materi apa yang harus dicapai, cara yang harus dipergunakan, alat-alat yang perlu disediakan dan bagaimana cara mengetahui hasil pencapaian hasil belajar; belajar tanpa menyadari pengalaman belajar yang sudah dimiliki; menganggap belajar sama dengan menghafal; belajar tanpa konsentrasi pikiran.

Kesulitan Belajar adalah suatu kelainan yang membuat seseorang sulit dalam suatu kegiatan belajar yang efektif [3]. Kesulitan 
belajar dapat di identifikasi sampai anak tersebut mengalami kegagalan dalam menyelesaikan tugas akademiknya. Beberapa faktor yang mempengaruhi kesulitan belajar siswa diantaranya adalah sebagai berikut :

a. Faktor yang bersumber dari diri sendiri

b. Faktor yang bersumber dari masyarakat

c. Faktor yang bersumber dari keluarga

d. Faktor yang bersumber dari lingkungan sekolah [4]

Di SMA Uswatun Hasanah ada beberapa siswa yang berlatarbelakang dari keluarga broken home sehingga guru matematika kesulitan dalam memberikan pembelajaran, untuk itulah penulis tertarik dan bermaksud untuk menganalisis kesulitan belajar matematika yang berlatarbelakang dari keluarga broken home sehingga menemukan solusi yang tepat untuk menyelesaikan masalah siswa yang sulit dalam belajar matematika karena mempunyai keluarga yang tidak sakinah. Dalam penelitian ini penulis berkontribusi kepada anak - anak yang mempunyai keluarga broken home yaitu memberikan suatu cerita pengalaman untuk memotivasi anak tersebut dan memberikan solusi cepat dalam mengerjakan soal yang berkaitan dengan matematika sehingga siswa tersebut lebih tertarik lagi dengan mata pelajaran matematika.

\section{METODE}

Penelitian ini dilaksanakan di SMA Swasta Uswatun Hasanah di Jl. Depnaker no.2 Pinang Ranti Kp Makasar Jakarta Timur. Jenis penelitian ini adalah penelitian kualiatif deskriptif dengan metode yaitu penelitian dan pengembangan (Research and Development). Kegiatan ini dilaksanakan tahun 2017 pada semester ganjil. Responden dari penelitian ini adalah guru mata pelajaran matematika, guru BK dan peserta didik dari keluarga broken home. Jumlah peserta didik yang dijadikan sampel dari penelitian ini diambil dengan teknik pengumpulan data secara bertahap (multistage sampling).

Model criterion-based selection digunakan untuk menentukan subjek penelitian dengan berasumsi bahwa pemeran dalamtema penelitian yang dilaksanakan adalah subjek tersebut. Sedangkan model snow ball sampling digunakan untuk menentukan informan untuk memperluas subjek. Penelitian kualitatif sangat dipengaruhi oleh kualitas informasi yang sesuai dengan judul.

Ada dua tujuan penelitian kualitatif yaitu yang pertama menggambarkan dan mengungkapkan, serta yang kedua menggambarkan dan menjelaska. Deskriftif adalah sifat dari penelitian kualitatif karena tujuannya adalah untuk menggambarkan dan mendeskripsikan kejadian-kejadian yang bersifat natural atau alamiah maupun hasil olahan manusia. Di sisi lain penelitian ini juga mengkaji karakteristik, aktivitas, bentuk,perubahan, hubungan, kesamaan dan perbedaannya dengan kejadian yang lain. [5]

Yang dijadikan subjek dalam penelitian ini adalah siswa yang berlatarbelakang dari keluarga broken home di SMA Uswatun Hasanah. Pengumpulan data pada penelitian ini adalah dengan berbagai cara yaitu dengan wawancara, observasi, dan dokumentasi yang diperoleh dari subjek penelitian dan yang terlibat di dalamnya.

\section{Wawancara}

Wawancara adalah suatu metode yang dilakukan untuk mengupas informasi dengan cara membuat pertanyaan terlebih dahulu yang relevan dengan judul penelitian. Jawaban dari informan itu adalah sebagai acuan untuk menganalisa 
anak broken home yang mengalami kesulitan dalam belajar matematika.

\section{Observasi}

Metode ini dilakukan baik secara langsung dan tidak langsung. Secara langsung artinya melakukan pengamatan langsung di dalam kelas untuk mengetahui kegiatan anak broken home ketika belajar matematika. Sedangkan pengamatan secara tidak langsung yaitu pengamatan dari luar kelas dimana anak tersebut tidak mengetahui jika mereka sedang diawasi. Proses pembelajaran berlangsung ditulis dan dicatat setiap waktunya di lembar observasi atau lembar pengamatan untuk mengetahui sejauh mana kesulitan belajar matematika yang dihadapi anak broken home.

\section{Dokumentasi}

Metode dokumentasi yang dimaksud adalah mengumpulkan data pada waktu proses pembelajaran yang berkaitan dengan sikap pada waktu belajar di dalam kelas dan untuk mengetahui metode apa yang dipakai oleh guru matematika dalam pembelajaran di dalam kelas. Dokumentasi ini juga melihat nilai hasil ulangan anak broken home.

\section{HASIL DAN PEMBAHASAN}

Masalah yang relevan dengan matematika adalah ketika anak-anak kesulitan dalam memamahi materi pelajaran. Anak - anak sulit memahami konsep logika dan prinsip logika matematika dikarenakan berbagai faktor internal dan eksternal (Pujadi 2007) dalam [6].

Faktor internal yang membuat anak kesulitan dalam matematika adalah (a) dikarenakan minat anak yang rendah dalam belajar matematika dikarenakan selalu mendapatkan nilai yang rendah, (b) terlalu banyaknya hafalan rumus dan catatn materi matematika yang diberikan guru dan (c) sedikitnya minat belajar secara berkelompok. Sedangkan faktor eksternalny adalah (a) metode guru dalam menjelaskan materi kurang menarik, (b) tidak adany alat peraga dalam penyampaian materi. [5]

Selama tiga bulan melakukan pengamatan dan penelitian di SMA Uswatun Hasanah, penulis dapat melihat proses pembelajaran matematika dan siswa keluarga broken home ketika sedang belajar di kelas. Berikut ini adalah hasil wawancara dan observasi di Sekolah Menengah Atas Uswatun Hasanah.

Sekolah Menengah Atas Uswatun Hasanah mempunyai Sembilan kelas yaitu :

\begin{tabular}{cl}
\multicolumn{2}{c}{ Tabel. 1 Nama Kelas } \\
\hline No & Nama Kelas \\
\hline 1. & X MIPA 1 \\
2. & X MIPA 2 \\
3. & X IPS \\
4 & XI MIPA 1 \\
5. & XI MIPA 2 \\
6. & XI IPS \\
7. & XII MIPA 1 \\
8. & XII MIPA 2 \\
9. & XII IPS \\
\hline
\end{tabular}

Dari 9 kelas di SMA Uswatun Hasanah ada dua siswa dari keluarga broken home, masalah keluarga yang dihadapi siswa sangat menghambat mereka dalam proses pembelajaran matematika khususnya. Keadaan malas, terlambat ke sekolah bahkan yang jarang sekali masuk ke kelas juga ada, dan ketika dikonfirmasi kepada orang tuanya, mereka mengatakan bahwa anaknya sudah pergi ke sekolah. Hasil belajar matematika yang diperoleh sangat kurang.

Setelah melakukan wawancara dengan guru matematika yang mengajar siswa yang mempunyai masalah dengan keluarganya tersebut, beliau menjelaskan bahwa anak tersebut sebetulnya masih bisa mengikuti pembelajaran, tapi harus dengan penanganan yang khusus, karena kalau 
tidak ditangani dengan khusus anak tersebut akan sangat malas untuk belajar bahkan sampai tidur di kelas. Sedangkan menurut guru BK di sekolah SMA Uswatun Hasanah tersebut, psikis anak tersebut sudah terkena yang diakibatkan oleh masalah keluarganya sehingga terbawa ke sekolah, dan hasilnya hampir setiap mata pelajaran anak tersebut mempunyai masalah di kelas dengan gurunya. Ketika ditanyakan langsung kepada anaknya, anak tersebut mengatakan sudah tidak mempunyai semangat dan motivasi lagi untuk belajar. Maka oleh karena itu siswa yang mempunyai masalah dengan keluarganya akan mengalami kesulitan dalam belajar matematika. Adapun solusi yang sudah dilaksanakan oleh guru matematikanya adalah memberikan wawasan dan pengertian serta motivasi kepada anak tersebut untuk bisa melupakan dahulu masalah di kelurganya di kelas sehingga dapat focus dalam pembelajaran matematika. Sedangkan guru BK selalu memberikan nasihat-nasihat seminggu tiga kali kepada anak tersbut untuk memotivasi psikis anak tersebut ke arah yang lebih baik.

Menurut A. Muri Yusuf (1995:86) dalam [7] menjelaskan bahwa peranan guru mata pelajaran sangat penting dan diperlukan suatu kerja sama timbal balik antar guru bimbing konseling dan guru mata pelajaran dalam mengatasi kesulitan belajar yang dihadapi anak.

Ketika mewawancarai wali kelasnya, beliau sudah mengunjungi rumah anak broken home tersebut dan bertemu dengan keluarganya, dan guru wali kelasnya bilang pihak keluarga menyerahkan sepenuhnya kepada pihak sekolah minta dibantu untuk mendidik anaknya untuk menjadi lebih baik.

Pada saat observasi di SMA Uswatun Hasanah dengan secara tidak langsung artinya hanya mengamati siswa tersebut dari luar kelas ketika pembelajaran matematika berlangsung, terlihat anak yang mempunyai masalah dengan keluarganya tersebut murung tidak bergairah cenderung mengantuk, ketika siswa yang lainnya semangat kerja kelompok, anak broken home ini lebih mengasingkan diri dengan bermain alat komunikasi HP. Sesekali guru matematikanya menghampiri untuk menegur dan memberikan motivasi.

Kurikulum yang dipakai di SMA Uswatun Hasanah ini menggunakan kurikulum 2013, dimana setiap guru diharuskan menggunakan pendekatan scientific, supaya dapat mengetahui bakat dan karakter peserta didiknya. Segala upaya sudah dilakukan oleh pihak sekolah terkait peserta didik yang mempunyai masalah dengan keluarganya, ada yang berubah dari peserta didik tersebut ke arah yang lebih baik, ada pula peserta didik yang tidak bertahan di sekolah dan akhirnya putus sekolah.

\section{SIMPULAN}

Berdasarkan hasil penelitian yang telah dilakukan, maka disimpulkan bahwa peserta didik yang mempunyai masalah dengan keluarganya atau broken home, berpengaruh terhadap kegiatan belajarnya di kelas, sehingga peserta didik yang bermasalah dengan keluarganya kesulitan dalam belajar matematika itu dikarenakan psikis anak yang di rumahnya terdapat masalah terbawa ke kelas sehingga anak tersebut tidak bisa focus dan sangat malas dan hasilnya tidak bisa mengikuti materi matematika yang disampaikan gurunya. Kesulitan belajar matematika yang dihadapi anak broken home juga tidak adanya interaksi di dalam kelas sehingga membuat anak tidak dapat memahami setiap materi yang disampaikan oleh guru.Oleh karena itu proses pembelajaran siswa yang mempunyai masalah dengan keluarganya di rumah perlu penangan 
khusus dari berbagai pihak yaitu guru matematia, wali kelas guru $\mathrm{BK}$, sehingga dengan adanya mereka dengan atensi, motivasi dan wejangan dapat membangkitkan gairah anak tersebut dalam pembelajaran matematika, dengan mengurangi atau menghilangkan pikiran negative masalah keluarga yang dialamainya.

Esensi dari hasil penelitian ini adalah dampak negatif dari masalah keluarga terhadap anak dalam proses pemblajaran matematika. Sehingga dibutuhkan motivasi dari pihak sekolah supaya anak tersebut bangkit dan bisa melewati masalah yang dihadapi dan lebih semangat dalam pembelajaran matematika khususnya.

\section{UCAPAN TERIMAKASIH}

Ucapan terimakasih penulis sampaikan kepada pihak sekolah yang sudah memberikan izin kepada penulis supaya bisa melakukan penelitian di SMA Uswatun Hasanah,yakni Bapak Jalaluddin, S.Ag M.Si selaku kepala sekolah. Dan tak lupa penulis ucapkan terimakasih banyak yang sebesar-besarnya kepada Ibu Miranti, S.Pd selaku guru matematika, Ibu Sofi Selaku guru BK dan ibu Heni Selaku wali kelasnya, terimakasih sudah berkenan untuk diwawancarai.

\section{DAFAR PUSTAKA}

[1] S. Hafizah, and M. Mawarpury. "Pemaknaan Kebahagian oleh
Remaja Broken Home". Jurnal Ilmiah Psikologi. (5)1 . Hal: 59-66. 2018.

[2] Willis, Sofyan. S. Remaja \& Masalahnya. Bandung : Alfabeta. 2008.

[3] Jamaris, Martini. Kesulitan Belajar Prespekif, Asesmen, dan Penanggulangannya. Bogor: Ghalia Indonesia. 2014

[4] E. M. Yeni. "Kesulitan Belajar Matematika di Sekolah Dasar". JUPENDAS, vol. $\quad$ (2) 2.2015 .

[5] R. S. Waskitoningtyas. " Analisis Kesulitan Belajar Matematika Siswa Kelas V Sekolah Dasar Kota Balikpapan Pada Materi Satuan waktu Tahun Ajaran

2015/2106". Jurnal Ilmiah Pendidikan Matematika. (5) 1. Hal: 24-32. 2016.

[6] D. H. Harahap And R. Syarifah, "Studi Kasus Kesulitan Belajar Matematika Pada Remaja". Jurnal Psikologi. (11) 1. Hal: 20-30. 2015.

[7] Sudirman, Daharnis, and Marjohan. "Peran Guru Bimbingan Konseling serta Peran Guru Mata Pelajaran Dalam Mengatasi Kesulitan Belajar Siswa Di Sekolah Menengah Atas (SMA) Negeri". Jurnal Ilmiah Konseling. (2) 1. Hal: 120-124. 2013 